\title{
OVER EENIGE NIEUWE OPVATTINGEN IN DE CELLEER
}

\author{
door M. A. van Herwerden:
}

De mensch heeft van nature een ordenenden geest en het kan niet anders, of VIRchow's uitspraak: „omnis cellula e cellula” moet bij onze biologische voorouders een gevoel van verademing hebben gewekt. Na het chaotisch gedacht ontstaan van de cel uit een vormlooze massa, moet de feitelijke vaststelling van haar filialiteit een buitengewone orde in het biologisch brein hebben geschapen. Tegelijk met de cel werd nu ook aan de celkern een permanente bestaans. cyclus toegekend. En daarbij is het niet gebleven. Nog een ander gewichtig bestanddeel van de cel, namelijk het centrosoma, heeft men met een overeenkomstige eerbiedwaardige reeks van voorvaders bedacht; en nauwelijks heeft de jonge cytologie zich meester gemaakt van die andere merkwaardige lichamen in de cel, de mitochondria, of ze tracht ook deze in een stamlijst vast te leggen.

In een tijd, dat alles wankelt, begint er echter eveneens geschud te worden aan de hechte begrippen omtrent continuiteit en het is zaak met geopend oog, doch tevens met hritischen blik de nieuwe onderzoekingen en gegevens te volgen.

Het eerst is het het centrosoma geweest, dat den huidigen docent in de cytologie moeilijke overwegingen is gaan bezorgen. Tot in het schematische toe had men zich den cyclus van het centrosoma voor oogen gesteld; zelfs de bioscoop heeft zich van dit merkwaardig deelingsproces der centriolen meester gemaakt. Voet voor voet kon men de stralingen der uiteenwijkende centrosomen volgen. Totdat als rustverstoorder J. LoEB bij zijn merkwaardige proeven over kunstmatige parthenogenesis in een eiplasma, vrij van centrosomen, plotseling uni- of pluripolaire stralingen zag ontstaan en E. Wilson - is er nauwkeuriger onderzoeker dan deze? - cytologisch in het centrum dezer stralingen de aanwezigheid van een 
klassiek centrosoma in optima forma bevestigen kwam. Daar doken dus plotseling in het celplasma als speciale differentiaties van de cel centrosomen op. Elke samenhang met een moedercentrosoma, dat reeds lang tevoren bij de vorming der poollichaampjes het ei verlaten had, was onnaspeurbaar en zeer gekunsteld mocht het heeten nog eenig verband hiermede te willen zoeken. Die nieuwgevormde dynamische centra in de cel deden, zelfs wat hun deelingsvermogen betreft, niet voor het permanente celorgaan, zooals dit zich bij de mitose sedraagt, onder. Toch was door deze ontdekking in de onverbiddelijke continuiteit van het centrosoma voor goed een bres geslagen.

Onaangetast in haar waardigheid stond nog de kern met haar reeks van voorgeslachten, terugreikend tot . . . . ja tot wanneer? Tot haar staat van isolement, volgens de voorstelling van MERESCHKowsKY, totdat ze in den oertijd in symbiose met een eveneens zelfstandig levend celplasma trad? Of tot het fabelachtig verleden, toen ze in den vorm van chromatinekorrels in alle naktheid stond en eerst langzamerhand de bestanddeelen om zich heen verzamelde, die haar ingewikkelden bouw van heden deden ontstaan, zooals de hypothese van MiNchin verlangt? Hoe het $z \mathrm{ij}$, haar verleden scheen vlekkeloos, wat continuiteit betreft; een schijnbare uitzondering vormden slechts de eigenaardig gedifferentieerde kernen der infusoriën, waar de macronucleus in het celplasma wordt opgelost en door de generatieve kern wordt hersteld. Doch ook in dil geval is de nieuw gevormde macronucleus steeds materiaal, af komstig van een kern, welke laatste weer door een moederkern wordt voorafgegaan.

Moet men ook tegenover dit als bestendig opgevat gebeuren, heden toegankelijk zijn voor gewijzigde begrippen? Het is de waarneming van de eicel der Hymenopteren, welke ons dwingt in andere richting te zien. Ik heb hier het oog op de pas gepubliceerde onderzoekingen van $P$. Buchner in het Archiv f. microscopische Anatomie (Bd. 91, 1918, p. 1).

Reeds in 1886 waren door BLochmanN accessorische kernen in het mierenei beschreven, door den schrijver zelf als knopvormingen van de kern beschouwd, door andere onderzoekers in latere jaren voor kernen van follikelcellen gehouden, welke in het ei waren bínnengedrongen. BUCHNER heeft behalve bij het mierenei, bij een reeks van $\mathrm{Hymenopteren} \mathrm{dit} \mathrm{verschijnsel} \mathrm{onderzocht.} \mathrm{Voet} \mathrm{voor} \mathrm{voet}$ 
meent hij de genese van deze algemeen voorkomende accessorische kernen vervolgd te hebben en kan tot geen ander besluit komen, dan dat ze ter plaatse in het eiplasma of in het celplasma der voed. stercellen zonder onmiddellijke afhankelijkheid van de eikern ontstaan. Dat men inderdaad met kernen heeft te doen, blijkt uit de volkomen overeenkomst met den voor elke diersoort standvastigen, doch onderling zeer verschillenden bouw van de eikern. Alle overgangen van basophile korrels tot korrels omgeven door een fijn linine-netwerk en kernmembraan zijn in het celplasma waar te nemen. De basophile korrel wordt tot kernlichaampje (karyosoma) van de nieuwe kern, welke - eenmaal gevormd - zich door insnoering kan vermenigvuldigen. Een stroom van dergelijke chromatische korrels meent Buchner uit de voedstercel in de eicel te zien overgaan. Andere ziet men in de omgeving van de eikern zelf gelegen en dit verschijnsel gaat veelal gepaard met knopvorming van de zeer talrijke kernlichaampjes, welke zich binnen de eikern bevinden. Bewijzen voor uittreden van deze elementen uit de kern werden overigens niet gevonden, zoodat ook aan de mogelijkheid van een genese der basophile korrels in het celplasma ter plaatse moet worden gedacht. De accessorische kernen, tijdens de eirijping ontstaan, ver$\mathrm{d}$ wijnen weer door resorptie vóór het einde van dit proces. De vermoedelijke rol, die ze spelen bij de dooiervorming, geeft BUCHNER aanleiding ze trophonuclei te noemen.

Een generatieve beteekenis hebben de accessorische kernen der Hymenopteren dus niet en in dit opzicht kan het gemoed gerust zijn; het geloof in de waarschijnlijke overdracht door de kern van stoffen, die bij de overerving een rol spelen, wordt door deze mogelijke genese in het celplasma dus niet geschokt. Zijn het tenslotte toch, zooals BUCHNER niet onwaarschijnlijk acht, uit de kern afkomstige stoffen, die deze trophonuclei leveren, dan zou dit een heuglijk feit zijn voor den morpholoog-cytoloog, die zweert bij de chromidienleer en een emissie van chromatine uit de rijpende eicelkern als onomstootelijk feit aanneemt, ofschoon niemand hunner het uittreden tijdens het leven heeft waargenomen. Wie zich eenmaal overtuigd heeft, dat de fraaie rangschikking van korrels rondom de oöcytenkern, zooals men deze in het gefixeerde praeparaat ziet, in de levende cel tevergeefs wordt gezocht; dat tijdens het leven de korrels over het geheele celplasma liggen verspreid en eerst tijdens 
het afsterven der cel zich op de wijze der beschreven chromidien groepeeren, - is huiverig uit het gefixeerde praeparaat zulke vèrstrekkende conclusies te trekken als J. ScHAXEL en vele voorgangers uit de school van R. HERTwig hebben gedaan. Blijken het daarentegen plaatselijk gevormde chromatinekorrels ${ }^{1}$ ) te zijn, aan welke de vorming der trophonuclei is toevertrouwd, dan zou door dit onderzoek van BUCHNER - indien het bevestigd wordt - een brug worden gelegd tusschen de basophile korrels der bacteriën en de in. gewikkelde kernen der hoogere organismen.

Men moet bekennen, dat de uitvoerige publicatie van BuCHNer met fraaie af beeldingen verlucht, weinig plaats voor twijfel overlaat. De natuurlijke geneigdheid van menig waarnemer, wat naast elkaar gezien wordt, tevens genetisch met elkaar in verband te brengen, wekt bij den kritisch aangelegden lezer nog het verlangen een dergelijke genese tijdens het leven te volgen. Wellicht stelt een verbeterde techniek der weefselculturen buiten het organisme tot vervulling van dien wensch in staat.

1) Dat de basophile korrels in het eiplasma evenals de kernchromatine uit nucleinezuurverbindingen bestaan, is bij het zeeappelei door digestie met nuclease aangetoond (Arch. f. Zellforschung, X, 1912, blz. 431).

(Ingezonden 20 November 1918). 